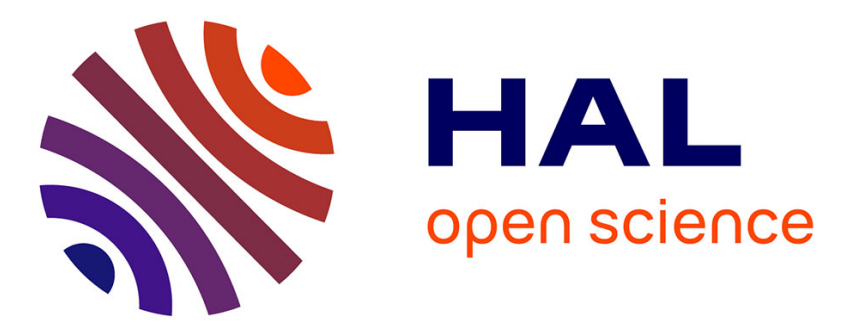

\title{
Neuropeptide Y signalling on Hippocampal Stem Cells in Health and Disease
}

\author{
William P. Gray
}

\section{To cite this version:}

William P. Gray. Neuropeptide Y signalling on Hippocampal Stem Cells in Health and Disease. Molecular and Cellular Endocrinology, 2008, 288 (1-2), pp.52. 10.1016/j.mce.2008.02.021 . hal00532008

\section{HAL Id: hal-00532008 https://hal.science/hal-00532008}

Submitted on 4 Nov 2010

HAL is a multi-disciplinary open access archive for the deposit and dissemination of scientific research documents, whether they are published or not. The documents may come from teaching and research institutions in France or abroad, or from public or private research centers.
L'archive ouverte pluridisciplinaire HAL, est destinée au dépôt et à la diffusion de documents scientifiques de niveau recherche, publiés ou non, émanant des établissements d'enseignement et de recherche français ou étrangers, des laboratoires publics ou privés. 


\section{Accepted Manuscript}

Title: Neuropeptide Y signalling on Hippocampal Stem Cells in Health and Disease

Author: William P. Gray

PII: $\quad$ S0303-7207(08)00109-3

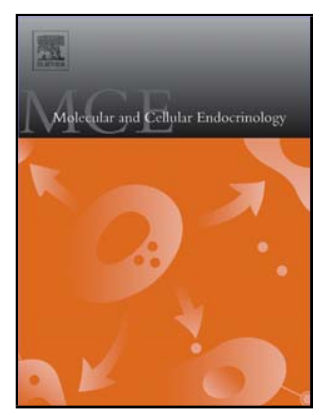

DOI: doi:10.1016/j.mce.2008.02.021

Reference: $\quad$ MCE 6834

To appear in: $\quad$ Molecular and Cellular Endocrinology

Received date: $\quad 23-10-2007$

Revised date: $\quad 7-2-2008$

Accepted date: $\quad$ 26-2-2008

Please cite this article as: Gray, W.P., Neuropeptide Y signalling on Hippocampal Stem Cells in Health and Disease, Molecular and Cellular Endocrinology (2007), doi:10.1016/j.mce.2008.02.021

This is a PDF file of an unedited manuscript that has been accepted for publication. As a service to our customers we are providing this early version of the manuscript. The manuscript will undergo copyediting, typesetting, and review of the resulting proof before it is published in its final form. Please note that during the production process errors may be discovered which could affect the content, and all legal disclaimers that apply to the journal pertain. 
Neuropeptide Y signalling on Hippocampal Stem Cells in Health and Disease

William P. Gray

Division of Clinical Neurosciences

Southampton Neurosciences Group

University of Southampton

Corresponding author:

Prof. William P. Gray

Address:

University Division of Clinical Neurosciences

Room LD70, South Academic Block,

Southampton General Hospital,

Southampton SO16 6YD

UK

w.p.gray@soton.ac.uk

phone ++442380794271

fax ++442380794542

\section{Acknowledgements:}

This work was grant supported by the Medical Research Council to WPG. 


\section{Summary:}

Neuropeptides are emerging as key components in the hippocampal neurogenic niche in health and disease, regulating many aspects of neurogenesis and the synaptic integration of newly generated neurons. This review focuses on the role of Neuropeptide $Y$ in the control of stem/precursor cells in the postnatal and adult hippocampus. It is likely that Neuropeptide Y releasing interneurons are key sensors of neural activity, modulating neurogenesis appropriately. This is likely to be a fruitful area of research for extending our understanding of the control of stem cells in the normal and diseased brain. 


\section{Contents}

1. Introduction / Outline

1.1 The dentate gyrus and adult hippocampus

1.2 Progenitor niches in the hippocampus and peri-hippocampal areas

\subsubsection{Granule Cell Layer of the Dentate gyrus}

\subsubsection{Caudal Subventricular and Subcallosal Zones}

2. Function of Hippocampal/Dentate Neurogenesis

3. Control of Dentate neurogenesis

4. NPY in the Hippocampus

5. NPY and hippocampal Neurogenesis

5.1 NPY is proliferative for nestin positive precursor cells and committed neuroblasts isolated from the entire hippocampus.

5.2 NPY is proliferative for nestin positive precursors from both the Dentate gyrus and Hippocampus/SVZ but is selectively proliferative for neuroblasts only from the dentate.

5.3 The proliferative effect of NPY on nestin and $\beta$-tubulin cells is Y1 receptor mediated.

5.4 NPY mediated proliferation in the dentate gyrus requires ERK1/2 activation.

5.5 NPY has a pure proliferative effect and does not instruct differentiation.

5.6 Germ line Y1 KO and NPY KO mice confirm a proliferative role for NPY via the $\mathrm{Y} 1$ receptor in-vivo.

6. NPY control of dentate neurogenesis 
7. NPY, Neurogenesis and cognitive function

8. NPY, behaviour and mood control

9. NPY and Stem Cells in the pathological / epileptic Hippocampus

9.1 NPY and Temporal lobe epilepsy

9.2 NPY and seizure induced stem cell proliferation

10. Conclusions 


\section{Introduction / Outline}

Over the last fifteen years there has been an explosion of interest in stem cell biology, particularly in the adult brain, since the realization of the importance of Joseph Altman's work demonstrating neurogenesis in the post natal dentate gyrus of the hippocampus (Altman \& Das, 1965). The hippocampus is involved in the learning and memory of explicit information (Eichenbaum, 1997) and with the amygdalar formation, is important in the generation of behavioural responses to stress. Given the emerging roles of postnatal neurogenesis in hippocampal dependant learning and behaviour, much research has concentrated on elucidating the function of hippocampal (or more properly granule cell layer) neurogenesis as well as determining factors that influence it (Gage, 2002). More recently, there is an emerging awareness of the effect of pathological processes on dentate neurogenesis and on possible roles of abnormal neurogenesis in the pathophysiology of disease. Disease may alter the production and or integration of newly born neurons within the dentate gyrus and hippocampus and therefore may be viewed as perturbating a physiological function such as mood (Jacobs et al., 2000) or hippocampal dependant learning (Shors, 2004), or create abnormal circuits that might subserve altered network activity, as in epilepsy (Parent, 2002; Scharfman \& Gray, 2006). Central to these questions are the mechanisms whereby neurogenesis is linked to neural activity.

Although the principle neural inputs into the dentate gyrus have been well defined, there is much evidence to suggest that local networks, largely sub-served by neuropeptide releasing interneurons, significantly modulate activity, and are thus ideally placed to signal neuronal activity to the local stem cell niche. This review highlights the emerging role of neuropeptides in modulating hippocampal neurogenesis. It focuses particularly on 
neuropeptide $\mathrm{Y}$, which is both released by dentate interneurons under specific firing frequencies in the dentate, and also from the sympathetic nervous system into the circulation (Lundberg et al., 1985; Pernow et al., 1986), crossing the blood brain barrier (Kastin \& Akerstrom, 1999) in the neurogenic subgranular zone (SGZ) of the dentate gyrus. The review first details relevant hippocampal anatomy and the principle neurogenic niches of the dentate gyrus, and caudal subventricular zones. It then briefly describes the putative roles of adult neurogenesis in the normal brain and summarises knowledge regarding its control. It then details the roles of neuropeptides, particularly NPY, in neurogenesis under normal conditions and those of pathology, mainly focusing on temporal lobe epilepsy, which is the main pathological state relevant to neuropeptides and neurogenesis investigated to date.

\subsection{The dentate gyrus and adult hippocampus}

Within the hippocampus, the adult dentate gyrus consists of a dense layer of glutamatergic granule cells, and many other types of neurons and glia that are dispersed throughout all strata (Fig. 1). The somata of granule cells are tightly packed, and form the so-called granule cell layer. Granule cells are oriented in a stereotypical fashion, with a spiny arbor of dendrites that begins at the cell body and extends unilaterally to the hippocampal fissure (Fig. 1). On the opposite pole of the granule cells from their dendrites lie the granule cell axons or "mossy fibers." These axons are a major component of the large region just beneath the granule cell layer, called the hilar region or hilus (Fig. 1). The mossy fibers primarily target the proximal apical dendrites of CA3 pyramidal cells of hippocampus, but also form a complex array of collaterals that 
terminate on hilar cells. These hilar cells are termed interneurons as they appear to modulate the local activity of granule cell neurons. They can be divided into the mossy cells, which innervate the inner third of the ipsilateral and contralateral granule cell layer, and hilar cells that are GABAergic, which are highly diverse in morphology and projection. The somata and axons of GABAergic neurons are located throughout the dentate gyrus. All of the cells in the dentate gyrus, both glutamatergic and GABAergic, contain secondary chemicals and proteins that are thought to be neuromodulators, and which are often cell-type specific. GABAergic neurons contain a variety of unique peptide neurotransmitters that are not normally expressed in other dentate gyrus neurons, such as neuropeptide Y, Galanin, PACAP, somatostatin, cholecystokinin, and vasoactive intestinal polypeptide, among others (Freund \& Buzsaki, 1996). NPY is normally expressed very specifically, in a subset of GABAergic neurons in the dentate hilus and in the pyramidal cell layers of the hippocampus, and not other cell types (Kohler et al., 1986; Deller \& Leranth, 1990), except for noradrenergic projection fibres arising from the locus coeruleus and terminating in the dentate hilus (Xu et al., 1998), suggesting that NPY can be released in the hilus and SGZ by the activation of largely intrinsic and some projection pathways. Many interneurons co-localize NPY with other peptides, including somatostatin and cholecystokinin. Most NPY-immunoreactive axon terminals appose molecular layer dendrites, of granule cells as well as other non-granular cells (Deller \& Leranth, 1990; Milner \& Veznedaroglu, 1992). NPY terminals also appose astrocytic processes (Pickel et al., 1995), suggesting an interaction with glia (Ubink et al., 2003). This may be especially relevant to neurogenesis as radial glia like astrocytes that extend 
processes through the granule cell layer into the inner molecular layer are the stem cells that give rise to newly generated granule cell neurons (Seri et al., 2001 and see below).

\subsection{Progenitor niches in the hippocampus and peri-hippocampal areas}

\subsubsection{Granule Cell Layer of the Dentate gyrus}

Unlike the rest of the hippocampus, which is generated from the hippocampal anlage at embryonic day 16 (E16), the granule cell layer of the dentate is largely generated postnatally. Cells of the second dentate migration form the tertiary matrix in the hilus of the developing dentate by postnatal day $3(\mathrm{P} 3)$, which generates approximately $50 \%$ of the granule cell layer after P5, and from where precursor cells migrate to the inner border of the granule cell layer to form the adult neurogenic subgranular zone (SGZ) by P20 (Fig. 1). The granule cell layer therefore develops as an inside-out structure with the newer cells being added successively along the inner margin initially from the tertiary germinal matrix and later from the subgranular zone (Schlessinger et al., 1975; Altman \& Bayer, 1990) (See Fig. 1). This neurogenic niche is the site of ongoing neurogenesis throughout adult life in all mammals studied to date including humans (Eriksson et al., 1998 ) and it has been estimated to generate $6 \%$ of the total granule cell population every month (Cameron \& McKay, 2001). Within the neurogenic subgranular zone (SGZ) of the dentate gyrus, astrocytes with a radial glia like morphology extending a single main process into the granule cell layer are primary progenitor cells (Type B cells) (Seri et al., 2004). Nestin is an intermediate filament protein which is expressed in progenitor/stem cells (Lendahl et al., 1990) in the SGZ. Using nestin driven fluorescent protein expression, Kempermann and colleagues have classified stem/progenitor cells in the SGZ 
as bipotent GFAP expressing Type 1 cells which have astrocytic properties and GFAP negative Type 2 and Type 3 lineage determined progenitor cells (for review see (Kempermann et al., 2004)) (Fig. 2). These different cells form a functional unit referred to as the stem cell niche in which Type 2 cells are held in the SGZ within a basket of processes arising from the cell body of the radial Type 1 cell, while Type 3 cells lie without the SGZ but with an intimate relationship between its apical dendrite and the radial process of the Type 1 cell which is thought to guide its migration into the molecular layer (Seki \& Arai, 1999; Seri et al., 2004; Shapiro et al., 2005).

\subsubsection{Caudal Subventricular and Subcallosal Zones}

Proliferating cells continue to be seen in the subventricular zone (SVZ), a remnant of the embryonic ventricular zones, which persists throughout life. In vivo, in rodents progenitors in the anterior SVZ give rise to chains of rostrally migrating cells called the rostral migratory stream that eventually reach the olfactory bulb where they differentiate into GABAergic and dopaminergic interneurones (Lois \& Alvarez-Buylla, 1993). In humans a similar pathway has been recently described between the lateral ventricle and the olfactory bulb (Curtis et al., 2007). The caudal subventricular zone of the lateral ventricle lines the superficial layer of the hippocampus over areas CA1 and CA3 and contains neural progenitors that develop into glia, giving rise to white matter astrocytes and oligodendrocytes in neonatal and juvenile rodents (Levison \& Goldman, 1993; Levison et al., 1999) as well as neurons that migrate to the olfactory bulb (Merkle et al., 2007). The adjacent contiguous subcallosal zone lies in a potential space between the extraventricular hippocampus and the overlying corpus callosum and generates 
oligodendrocytes that migrate radially to myelinate the major white matter tracts (Seri et al., 2006). Using transient mitotic inhibition Doetch et al (Doetsch et al., 1999) elegantly demonstrated a reconstitution of the SVZ neurogenic niche by the initial division of GFAP+ subependymal astrocytes (Type B cells), followed by GFAP negative nestin positive population of rapidly cycling cells (Type C cells) and lastly by proliferating neuroblasts (Type A cells). These A cells then continued proliferating whilst migrating towards the olfactory bulb surrounded by Type B and Type A cells in the rostral migratory stream (RMS). Dopaminergic periglomerular neurons originate predominantly from precursors in the RMS while granule interneurons arise from progenitors in the SVZ demonstrating specific regionalisation of olfactory bulb interneuron precursors (Hack et al., 2005). 


\section{Function of Dentate Neurogenesis}

The hippocampus has been repeatedly implicated in the modulation of cognition in association with learning and memory, and the demonstration of functional integration of these newly born dentate granule cells into hippocampal circuitry (Scharfman et al., 2000; van Praag et al., 2002) has led to the hypothesis that neurogenesis may be important in learning and memory formation (Gould et al., 1999; Shors et al., 2001; Snyder et al., 2001). Hippocampal dependant associative learning tasks increase dentate neurogenesis (Gould et al., 1999) and pharmacological reduction of newly born neurons in the dentate impairs certain types of hippocampal dependant learning such as trace conditioning (Shors et al., 2001). Moreover, prenatal stress produces learning deficits associated with inhibition of dentate neurogenesis (Lemaire et al., 2000) and the level of cell proliferation in the SGZ predicts the spatial memory performance of male rats in the water maze (Drapeau et al., 2003). Exposure to a novel or enriched environment increases neurogenesis largely by increasing the proportion of cells that survive and integrate (Kempermann et al., 1997) (for a critical review see (Prickaerts et al., 2004)). In addition, several avenues of research have suggested that decreased hippocampal neurogenesis may be important in the pathogenesis of depression (D'Sa \& Duman, 2002). Stress, which is often a requisite for depression, reduces hippocampal neurogenesis (Gould et al., 1997), tri-cyclic antidepressants increase hippocampal neurogenesis (Malberg et al., 2000) and the antidepressant induced increase in dentate neurogenesis appears to be necessary for their behavioural effects (Santarelli et al., 2003). As newly born neurons functionally integrate into hippocampal circuitry 2-3 weeks after birth 
(Hastings \& Gould, 1999; Markakis \& Gage, 1999), this may explain the puzzling 2-3 week delay in mood elevation after commencing antidepressants.

\section{Control of Dentate neurogenesis}

Despite an increasing knowledge of the structure of the SGZ neurogenic niche, our knowledge of the control mechanisms underlying hippocampal neurogenesis remains far from complete. Only a brief summary of the neuro-humoural control of dentate neurogenesis will be attempted here. For a more complete review the interested reader is referred to (Abrous et al., 2005). Circulating growth factors such as IGF1 increase hippocampal neurogenesis (O'Kusky et al., 2000) and may partly mediate the neurogenic effect of prolonged exercise, such as running, on dentate neurogenesis. Glucocorticoids depress cell proliferation and neurogenesis in the SGZ, while adrenalectomy has the opposite effect (Cameron \& Gould, 1994). In contrast, neurosteroids such as DHEA increase SGZ cell proliferation (Karishma \& Herbert, 2002). CNS inflammation has been shown to decrease neurogenesis in the SGZ (Ekdahl et al., 2003; Monje et al., 2003) as has the pro-inflammatory cytokine IL-6 (Vallieres et al., 2002). Moreover, autoimmune T cells program microglia to make their phenotype supportive of neuronal survival (Butovsky et al., 2005) and renewal (Butovsky et al., 2006) and contribute to the maintenance of neurogenesis and spatial learning in adulthood (Ziv et al., 2006). Although neurogenesis is clearly a neural activity driven process, precise details of the neuronal control of dentate neurogenesis remain to be elucidated. Glutamatergic afferent input negatively regulates dentate neurogenesis (Cameron et al., 1995; Deisseroth et al., 2004) and acts downstream of steroid control while serotonin increases SGZ cell 
proliferation (Brezun \& Daszuta, 2000). Input from the medial septum and forebrain also regulates hippocampal neurogenesis (Mohapel et al., 2005; Van der Borght et al., 2005). Although the principle neural inputs into the dentate gyrus have been well defined, there is much evidence to suggest that local networks, largely sub-served by GABAergic releasing interneurons, significantly modulate activity. Thus GABA has emerged as another candidate for excitation neurogenesis coupling (for review see (Ge et al., 2007)). Progenitors in the SVZ and dentate SGZ receive GABAergic input (Wang et al., 2003; Overstreet Wadiche et al., 2005; Wang et al., 2005), and while non synaptic GABA controls the proliferation of GFAP-expressing progenitors in the postnatal SVZ (Liu et al., 2005), it promotes neuronal differentiation and integration in the SGZ (Tozuka et al., 2005; Ge et al., 2006). In the dentate gyrus, GABAergic interneurons modulate granule cell excitability mainly via feedback circuits from mossy fibre collaterals (HIPP cells (Freund \& Buzsaki, 1996)) but also via feed forward circuits from entorhinal cortex and contralateral hippocampal inputs (Basket Cell interneurons) (Freund \& Buzsaki, 1996). They are thus ideally positioned to sample neuronal activity and signal it to the local stem cell niche. A subset of GABAergic interneurons co-release neuropeptides, usually under specific firing conditions. Principle among these is Neuropeptide Y, which is a powerful modulator of granule cell excitability (Colmers \& Bleakman, 1994; Vezzani et al., 1999b). A recent addition to the many physiological roles for NPY is as a proliferative factor for neural precursor cells, first demonstrated in the olfactory epithelium of adult mice (Hansel et al., 2001a). Here we review the emerging role of NPY as a modulator of dentate and hippocampal SVZ stem/precursor cells. 


\section{NPY in the Hippocampus}

Neuropeptide $Y$ is a 36 amino acid polypeptide neurotransmitter widely distributed in the mammalian central nervous system. It has a very high sequence homology spanning a large evolutionary spectrum from invertebrates to humans (Larhammar, 1996) suggesting important functions for this peptide. Known physiological functions within the CNS include the regulation of social and feeding behaviour (de Bono \& Bargmann, 1998; Sokolowski, 2003; Wu et al., 2003; Kalra \& Kalra, 2004), circadian rhythm (Albers \& Ferris, 1984; Albers et al., 1984) and central cardiovascular function (Pedrazzini et al., 1998). NPY has a number of cognitive and behavioural effects on alcohol intake (Thiele et al., 2004), learning and memory (Redrobe et al., 1999), the anxiety response to stress and the maintenance of normal mood (for review see (Heilig, 2004). Neuropeptides are synthesised as preprohormones, which undergo a number of cleavage steps initially in the endoplasmic reticulum and later in immature large core dense vesicles (LCDV) where they undergo proteolytic cleavage and post-translational modification to the final bioactive neuropeptide. The neuropeptide is released from LCDVs under specific firing conditions which are distinct from those for classical neurotransmitter release (Hokfelt et al., 1984). NPY is one of the many neuropeptides that undergoes post-translational amidation, and in mammals, amidated peptides serve as growth factors mediating cell survival and neuronal proliferation (Krsmanovic et al., 1993; Wettstein et al., 1995; Waschek et al., 1997). A recent addition to the many physiological roles for NPY is as a proliferative factor for neural precursor cells, first demonstrated in the olfactory epithelium of adult mice (Hansel et al., 2001a). Recent studies have begun to identify a role for a number of amidated neuropeptides in neural stem cell biology both in the 
developing and adult mammalian brain and particularly in the olfactory epithelium (for review see (Hansel et al., 2001b)).

Of the 5 NPY receptors known to be expressed in the brain, only Y1, Y2, and Y5 mRNA is robust in the dentate gyrus (Parker \& Herzog, 1999). mRNA for Y1, Y2, and especially Y5 receptors appear to be expressed primarily on hilar neurons and in granule cells (Parker \& Herzog, 1999). Receptor protein appears to have a different expression pattern, with Y2 and Y5 receptors primarily on mossy fibres and Y1 receptors primarily in the molecular layer and neurogenic subgranular and peri-hippocampal subventricular zones (Kopp et al., 2002a).

\section{NPY and hippocampal Neurogenesis}

We began to investigate a possible role for NPY in neurogenesis in the hippocampus using dissociated monolayer and neurosphere cultures harvested from the hippocampi of perinatal rat pups when the level of neurogenesis is at its highest, in order to optimise the number of stem/precursor cells in culture (for detailed methods see Howell et al 2003 (Howell et al., 2003) as well as in adult NPY (Howell et al., 2007) and NPY Y1 null mice (Howell et al., 2005).

\subsection{NPY is proliferative for nestin positive precursor cells and committed} neuroblasts isolated from the entire hippocampus.

We followed the progression of cell number, rates of division and phenotypic fate (Class III ß-tubulin (neuronal), GFAP (glial) and nestin (stem/precursor cell)) over 7 days in culture. BrdU was given for the final 24 hours before each time point as a marker of Sphase entry. Analysis from $72 \mathrm{~h}$ revealed significant increases in cell number, BrdU incorporation, nestin immunopositivity and Class III $\beta$ tubulin immunopositivity in NPY 
treated cultures relative to controls (Fig. 3 A-D). Nestin positive proliferating cells showed an exponential growth curve (Howell et al., 2003) (Fig. 3C). These were small unipolar or bipolar cells, with phase bright cell bodies typical of hippocampal stem/precursor cells previously described by Palmer et al (Palmer et al., 1997) (Fig. 3E). The time course of increases in B-tubulin expressing cells was different with a peak at 3 and 5 days in-vitro (DIV) after which the numbers plateaued (Fig. 3D), characteristic of terminally committed progenitors or Type 3 cells (Howell et al., 2003). There was no evidence of a trophic effect of NPY since cell death was not altered by NPY (Fig. 3F). Using short pulse BrdU experiments we confirmed a proliferative effect of NPY on both nestin positive precursors and committed $\beta$-tubulin positive neuroblasts (Fig $3 \mathrm{G \& H}$ ). Sphere cultures showed that the nestin positive cells that were NPY responsive were sphere forming and when grown under clonal conditions gave rise to neurons, astrocytes and oligodendrocytes (Howell et al., 2003; Howell et al., 2007) consistent with their categorisation as multipotent precursors. These cells were GFAP negative and rapidly cycling, consistent with Type 2 cells (vide supra).

\subsection{NPY is proliferative for nestin positive precursors from both the Dentate gyrus and Hippocampus/SVZ but is selectively proliferative for neuroblasts from the dentate.}

The hippocampus is not uniform in its neurogenic structure (Fig. 1). Precursor cells cultured from the caudal subventricular zone cSVZ are true stem cells capable of indefinite self renewal and are multipotent, generating neurons, astrocytes and 
oligodendrocytes, while precursor cells in the dentate gyrus are not easily passaged in culture, i.e. display a limited capacity for self-renewal (Seaberg \& van der Kooy, 2002). In order to ascertain which neurogenic population of precursor cells responds to NPY, we generated region specific microcultures from the dentate gyrus and the hippocampus proper (including the cSVZ) after Seaberg and van der Kooy (Seaberg \& van der Kooy, 2002).

The number of neurons (ClassIII $\beta$-tubulin expressing cells) was greater in control dentate vs hippocampus-only cultures as expected. However dentate cultures showed a selective increase in the number of neurons in response to $1 \mu \mathrm{M}$ NPY whereas hippocampal cultures did not (Howell et al., 2005). This was not due to a neurotrophic effect as both control and NPY treated dentate cultures had similar proportions of cell death. NPY had a proliferative effect only on cycling $\beta$-tubulin positive neuroblasts derived from the dentate gyrus and not from the hippocampus. This regional specificity was in contrast to a proliferative effect on nestin positive cells from both regions (Howell et al., 2005).

\subsection{The proliferative effect of NPY on nestin and $\beta$-tubulin cells is Y1 receptor mediated.}

A direct effect of NPY on cell proliferation is inferred from in-vitro experiments showing that fluorescently tagged NPY binds to proliferating BrdU positive cells in culture (Howell and Gray, unpublished data), and that both nestin and $\beta$-tubulin positive cells stain for the NPY Y1 receptor (Howell et al., 2003). Pharmacological studies using specific Y1, 2 and 5 receptor agonists and antagonists showed that the proliferative effect 
of NPY was mediated entirely by the Y1 receptor, which was confirmed by showing an absence of any proliferative effect of NPY on cultures from germ line Y1 -/- mice compared to wild-type controls (Howell et al., 2003). This Y1 receptor specificity was confirmed on both proliferating $\beta$-tubulin cells and nestin cells from the dentate gyrus (Howell et al., 2005; Howell et al., 2007) in culture. Studies in germ-line Y1 receptor knockout mice revealed significantly reduced BrdU incorporation in proliferating cells in the SGZ of the dentate (Howell et al., 2005) as well as the caudal subventricular zones and subcallosal zones (Howell et al., 2007; Laskowski et al., 2007). Germline Y1 deletion did not affect BrdU bioavailability, as BrdU incorporation in the hilus and areas CA1 and CA3 of the hippocampus showed no change between wild-type and Y1 KO.

\subsection{NPY mediated proliferation in the dentate gyrus requires ERK1/2 activation.}

The ERK kinases (extracellular signal-regulated kinases) are a group of mitogenactivated protein kinases (MAPK) important in control of cellular proliferation (LopezIlasaca, 1998) including neural progenitors (Li et al., 2001). Inhibition of ERK 1/2 phosphorylation by UO126 abolished the neuroproliferative effect of NPY on proliferating cells cultured from the dentate gyrus (Howell et al., 2005). This finding was in agreement with studies from the olfactory epithelium where ERK phosphorylation was necessary for NPY mediated proliferation of neuroblasts (Hansel et al., 2001a)

\subsection{NPY has a pure proliferative effect and does not instruct differentiation.}

When clonal spheres were generated from nestin positive progenitors, NPY significantly increased sphere number and size (Howell et al., 2007). Analysis of the phenotype of 
cells within the spheres was unchanged from those grown under control conditions and had a higher proportion of GFAP phenotype than those grown under combined FGF/EGF conditions. When these spheres were replated under differentiating conditions the welldescribed neurogenic effect of FGF/EGF was confirmed with a significantly increased proportion of neurons generated. In contrast NPY did not instruct differentiation and was purely proliferative for hippocampal precursors.

\subsection{Germ line Y1 KO and NPY KO mice confirm a proliferative role for NPY via the $\mathrm{Y} 1$ receptor in-vivo.}

Short survival (2 hours) and pulse and chase (21 days) BrdU experiments in adult germ line $\mathrm{Y} 1 \mathrm{KO}$ mice confirmed a reduction in S-phase BrdU incorporation two hours after intraperitoneal $\mathrm{BrdU}$ administration, consistent with a reduction in progenitor proliferation in the SGZ of the dentate (Howell et al., 2005). Sacrifice 21 days later showed no difference in the survival of BrdU labelled cells between $\mathrm{Y}_{1}{ }^{-/-}$and $\mathrm{Y}_{1}$ lox/lox wild type controls, again supporting the hypothesis that Y1 receptors had no effect on cell survival. Total cell counts in the granule cell layer in p35 and p90 mice showed no difference between $\mathrm{Y}_{1}^{-/}$and $\mathrm{Y}_{1}{ }^{\text {lox/lox }}$ controls, implying a compensatory increase in survival of newly generated neurons in constitutive $\mathrm{Y}_{1}{ }^{-/}$. Indeed reducing precursor proliferation using methylazoxymethanol (MAM) enhances the survival of newly born granule cells (Ciaroni et al., 2002).

Labelling proliferating progenitors for 5 days with daily doses of BrdU before sacrifice in $\mathrm{Y}_{1}{ }^{-/}$adult mice, confirmed a SGZ effect, but also showed a significant reduction in the cSVZ and SCZs between the hippocampus and the ventricle and overlying corpus 
callosum (Howell et al., 2007; Laskowski et al., 2007). Finally a similar BrdU labelling paradigm in adult NPY -/- mice again showed a significant reduction in BrdU incorporation in the dentate gyrus SGZ compared to wild-type controls (Howell et al., 2007). These studies have demonstrated that germ line deletion of both the ligand and its receptor reduces proliferation in the neurogenic niche of the SGZ. Pharmacological experiments and germ line NPY deletion have also demonstrated a proliferative role for NPY via its Y1 receptor in neuroblasts of the olfactory epithelium of adult mice (Hansel et al., 2001a).

\section{NPY control of dentate neurogenesis}

The most likely origin of NPY for modulating dentate neurogenesis is from NPY releasing interneurons in the dentate hilus, as granule cell production of NPY is only induced after seizures (Gruber et al., 1994) (vide infra) or perforant path stimulation (Causing et al., 1996). The interneurons in the dentate gyrus that express NPY are heterogeneous, receiving diverse inputs and innervating a variety of dentate gyrus cell types, including axon projections to the SGZ, where they could release NPY. The neurogenic SGZ and the molecular layer of the dentate gyrus are rich in $\mathrm{Y}_{1}$ receptors (Kopp et al., 2002b), the functional significance of which has heretofore been unclear. NPY interneurons are thus ideally positioned to sample patterns of afferent and efferent activity and thus modulate neurogenesis via NPY release on $\mathrm{Y}_{1}$ receptor positive subgranular zone precursors. Volume transmission by released NPY acting via rapidly internalising $\mathrm{Y}_{1}$ receptors (Fabry et al., 2000) is a well recognised mechanism of action of NPY and is particularly attractive as a means of orchestrating the proliferation of 
populations of precursors in the dentate SGZ. Noradrenergic projection fibres from the locus coeruleus also release NPY, and this might be one pathway for NPY to stimulate proliferation after physical exercise and electroconvulsive shock therapy for depression, as both involve noradrenergic activation and elevate NPY and proliferation in the hilus and dentate gyrus (Modigh, 1976; Mikkelsen et al., 1994; Bjornebekk et al., 2006). The other possible origin of NPY that could modulate SGZ precursors is from the sympathetic nervous system, which releases NPY into the circulation (Lundberg et al., 1985; Pernow et al., 1986) crossing the blood brain barrier (Kastin \& Akerstrom, 1999) to the vascular neurogenic SGZ. Indeed exercise induced systemic NPY release (Lundberg et al., 1985) may also play a role in mediating the exercise induced increase in dentate neurogenesis (van Praag et al., 1999).

\section{NPY, Neurogenesis and cognitive function}

Dentate neurogenesis also appears to be necessary for some forms of hippocampal dependant learning (Shors, 2004). NPY appears to have a role in learning and memory, albeit less established than in anxiety. Intracerebroventricular injections of NPY fragments have been shown to enhance memory retention, recall and prevent scopolamine induced amnesia (Flood et al., 1987) especially when injected into the rostral hippocampus (Flood \& Morley, 1989). NPY attenuates learning impairments induced by MK-801 (Bouchard et al., 1997) and the Y2 receptor also appears to be important in learning and memory processing (Redrobe et al., 2004). Although we found no in-vitro evidence for a direct Y2 receptor mediated effect on neurogenesis, Redrobe et al's Y2 knockout study is consistent with our data supporting a Y1 mediated effect on SGZ proliferation since Y2 receptors are considered to be autoreceptors that negatively 
feedback to NPY-ergic terminals to reduce NPY release (Colmers \& Bleakman, 1994) and so Y2 receptor null mice are predicted to have increased endogenous NPY expression. Studies in hippocampal NPY over expressing rats have shown impaired spatial learning associated with decreased NPY- Y1 binding in young animals (Thorsell et al., 2000) but normal spatial learning in old animals (Carvajal et al., 2004). It is interesting to note that NPY levels are reduced in the dentate gyrus of aged animals (Higuchi et al., 1988) as is neurogenesis and so neurogenesis in aged animals may be resistant to changes in NPY expression.

\section{NPY, behaviour and mood control}

Both laboratory (Heilig et al., 1989) and clinical studies (Morgan et al., 2000; Morgan et al., 2002) have implicated NPY in the regulation of anxiety related behaviours and the central anxiolytic effect of NPY appears to be $\mathrm{Y}_{1}$ receptor mediated (Wahlestedt et al., 1993; Sajdyk et al., 1999). Clinical studies have also reported reduced NPY in the cerebrospinal fluid and plasma from depressed patients (Westrin et al., 1999). Animal models of depression (Caberlotto et al., 1999; Husum \& Mathe, 2002) have reduced hippocampal levels of NPY and altered $\mathrm{Y}_{1}$ binding levels, antidepressants increase brain levels of NPY (Heilig et al., 1988) and the antidepressant-like activity of NPY appears to be mediated via the $\mathrm{Y}_{1}$ receptor (Redrobe et al., 2002). NPY has been shown to be involved in the antidepressant actions of lithium, electroconvulsive therapy (ECT) and Citalopram (Husum et al., 2000), all of which increase neurogenesis (Chen et al., 2000; Madsen et al., 2000; Malberg et al., 2000) and the NPY gene is one of the few genes whose expression is increased only with chronic ECT (Altar et al., 2004). For a comprehensive discussion of the role of the NPY system in stress, anxiety and 
depression, the reader is referred to a review by Marcus Heilig (Heilig, 2004). More recently this group have also shown that the Y1 receptor is necessary for the anxiolytic effects of NPY, but not for the antidepressant effects of fluoxetine (Karlsson et al., 2007). 


\section{NPY and Stem Cells in the pathological / epileptic Hippocampus}

\subsection{NPY and Temporal lobe epilepsy}

NPY expression in the rat dentate gyrus dramatically increases after seizures (Sperk et al., 1992; Vezzani et al., 1996; Vezzani et al., 1999a), and the upregulation of NPY in the dentate gyrus has become an accepted marker of seizure activity. After acute seizures (lasting minutes), there is an elevation of expression in many non-granule cells, particularly those in the hilus and granule cell layer. After more severe seizures, such as status epilepticus following electrical stimulation, kainic acid or pilocarpine administration (Sperk et al., 1992), this acute upregulation also occurs, but in addition some of the NPY cells die due to excitotoxicity (Mitchell et al., 1997). When seizures occur chronically, there continues to be an increase in NPY expression in non-granule cells, but in addition, NPY is apparent in the granule cells and their axons (Marksteiner et al., 1990; McCarthy et al., 1998) and NPY immunolabeling becomes distributed throughout the mossy fiber axon plexus. Axonal sprouting of NPY-immunoreactive GABAergic neurons that survive seizures (Vezzani \& Sperk, 2004) may compensate for the loss of some of the original NPY-containing neurons. There are substantial changes in NPY receptor expression after seizures. Y2/Y5 receptors mainly increase and Y1 receptors appear to decrease. These changes in NPY and Y2/5 receptor upregulation are consistent with a compensatory reaction that serves to increase seizure threshold and which may be neuroprotective. This follows logically from studies showing that NPY depresses mossy fiber transmission. For a comprehensive review see (Vezzani et al., 1999b). 
The majority of studies support the concept that increased neuronal activity increases neurogenesis in the dentate gyrus. Therefore, it is not surprising that seizures also increase neurogenesis. One of the first studies of this kind showed that a single afterdischarge was sufficient to increase proliferation (Bengzon et al., 1997). Subsequent studies illustrated that seizures produced by many different methods could increase neurogenesis. For example, status epilepticus initiated by the systemic administration of the chemoconvulsant pilocarpine i.p. (Parent et al., 1997) or intracerebroventricular kainic acid (Gray \& Sundstrom, 1998) led to an increase in neurogenesis. Subsequent studies have provided even more evidence for the robust nature of seizure-induced neurogenesis using laboratory animals (Covolan et al., 2000; Nakagawa et al., 2000; Ferland et al., 2002; Jiang et al., 2003), and the ability of seizures to influence proliferation of the radial glia-like precursors (Huttmann et al., 2003) and type 2 doublecortin positive cells (Jessberger et al., 2005) that become granule cells. More recently studies have shown that in addition to increasing the rate of neurogenesis, they facilitate the maturation and assimilation of new cells into hippocampal circuitry (Overstreet-Wadiche et al., 2006), generate ectopic granule cells (Scharfman et al., 2000) which may contribute to hyperexcitability, and permanently alter the connectivity of subsequently born granule cell neurons (Jessberger et al., 2007). The relevance of these findings to the development of the epileptic state after a signal episode of status epilepticus as occurs in children after complex febrile convulsions, is an exciting area of translational research, central to which is an understanding of the mechanisms subserving seizure induced neurogenesis. 
These mechanisms underlying seizure-induced neurogenesis/ gliogenesis are incompletely understood, but clearly involve an increase in precursor cell proliferation. Seizures increase the proliferation of neuroblasts in the rostral SVZ (Parent et al., 2002) and of both radial glia-like precursor cells (Huttmann et al., 2003) and doublecortinpositive cells in the SGZ of the dentate gyrus (Jessberger et al., 2005). One of the aspects of seizures that is perhaps as robust as their ability to increase neurogenesis of granule cells, is their induction of increased NPY expression in the dentate gyrus. It is therefore possible that the increase in NPY at least partly mediates the increase in neurogenesis of granule cells. In support of this hypothesis, the experimental seizure models that have demonstrated increased neurogenesis are models that have also shown an increase in NPY. Second, the increase in NPY is rapid (Marksteiner et al., 1989), and occurs before neurogenesis begins, as would be necessary if neurogenesis is dependent on NPY. Thirdly, as reviewed above, NPY is proliferative for precursor cells in the dentate SGZ and also in the caudal SVZ where seizures also induce precursor proliferation.

\subsection{NPY and seizure induced stem cell proliferation}

To examine if NPY could be a modulator of proliferation in response to seizures, we examined SGZ cell proliferation following kainic acid-induced seizures in 3 month-old adult male NPY -/- mice and controls. NPY-/- animals are more sensitive to seizure induction (Erickson et al., 1996) and required a "low dose" of kainic acid to display prominent equivalent seizures to wild-type mice.

We found that NPY strongly contributes to baseline and seizure-induced precursor proliferation in the SGZ, as proliferation was significantly reduced in NPY-/- mice under both conditions. Seizure-induced proliferation in NPY-/- animals was significantly 
reduced compared to both kainate-dose matched and seizure-severity matched controls. There was no significant difference between the levels of proliferation when wild-type animals were given low or high doses of kainate, suggesting that the level of limbic seizure activity was similar in each. The greater intensity of hilar and granule cell layer NPY immunostaining was consistent with a seizure-induced increase in NPY expression as previously reported (Marksteiner et al., 1989) and we found no immunostaining for NPY in NPY-/- tissue. Interestingly, although the absolute levels of proliferation were lower in the NPY -/- animals in control conditions and after kainate, the relative increase after kainate was the same in the wild type and NPY-/- groups ( 4.4 fold and 4.7 fold respectively), implying that SGZ proliferation under control conditions and after seizures is not mediated entirely via NPY, and that at least in the constitutive knock out, other mechanisms were able to induce a seizure-induced response but were unable to fully compensate for loss of the NPY-mediated effect. Both FGF2 (Yoshimura et al., 2001), serotonin via its 5HT1A receptor (Radley \& Jacobs, 2003) and Galanin via its GalR2 receptor (Mazarati et al., 2004) have also been implicated in seizure induced proliferation and cell survival in the dentate.

The caudal SVZ and SCZ contain constitutively active oligodendrocyte precursors, a proportion of which arise from SVZ Type B stem cells, which generate postnatal oligodendrocytes that contribute to the myelination of white matter tracts in the corpus callosum and fimbria fornix (Menn et al., 2006). The cSVZ and SCZ also contain a prominent band of cellular Y1 receptor staining (Kopp et al., 2002b) and the proliferation of these stem/precursor cells in the cSVZ is increased after seizures (Parent et al., 2006). We confirmed an effect of NPY on proliferation in the adult cSVZ and SCZ under control 
conditions in NPY Y1-/- mice (Howell et al., 2007). We also found that proliferation in the SCZ under control conditions and after seizures was mediated by NPY (Laskowski et $a l ., 2007)$ consistent with the hippocampal nestin positive cell population identified in our in-vitro culture system. Our results raise the intriguing possibility that some of the NPYresponsive ß-tubulin-negative population in our postnatal HSVZ cultures are oligodendrocytes precursors, such that NPY modulates cSVZ and SCZ oligodendrogliogenesis as well as SGZ neurogenesis.

\section{Conclusions}

The significance of our results lies in the identification of NPY, and therefore NPYreleasing interneurons, as important modulators of the proliferation of precursor cells in both the dentate SGZ and caudal SVZ and SCZ under normal conditions and after seizures. Given that hilar and hippocampal interneuron loss is a prominent and early feature of mesial temporal lobe epilepsy, which is associated with cognitive decline, then targeting this population for neuroprotection, or pharmacological replacement, may ameliorate or reverse cognitive deficits by preventing or restoring the impaired neuropeptide drive on adult precursor cells.

These findings also support the concept that NPY and other neuropeptides have a ubiquitous role across all of the stem cell niches in the adult brain. It remains to be seen whether different neuropeptides have distinct roles in the recruitment, proliferation, differentiation of precursor cells as well as the survival of their newly generated progeny. Lastly, understanding the role of neuropeptides in the stem cell niche should enhance its 
pharmacologically modification in an effort to effect repair of the damaged niche after acute or chronic brain injury. 


\section{References}

Abrous, D.N., Koehl, M. \& Le Moal, M. (2005) Adult neurogenesis: from precursors to network and physiology. Physiol Rev, 85, 523-569.

Albers, H.E. \& Ferris, C.F. (1984) Neuropeptide Y: role in light-dark cycle entrainment of hamster circadian rhythms. Neurosci Lett, 50, 163-168.

Albers, H.E., Ferris, C.F., Leeman, S.E. \& Goldman, B.D. (1984) Avian pancreatic polypeptide phase shifts hamster circadian rhythms when microinjected into the suprachiasmatic region. Science, 223, 833-835.

Altar, C.A., Laeng, P., Jurata, L.W., Brockman, J.A., Lemire, A., Bullard, J., Bukhman, Y.V., Young, T.A., Charles, V. \& Palfreyman, M.G. (2004) Electroconvulsive seizures regulate gene expression of distinct neurotrophic signaling pathways. $J$ Neurosci, 24, 2667-2677.

Altman, J. \& Bayer, S.A. (1990) Migration and distribution of two populations of hippocampal granule cell precursors during the perinatal and postnatal periods. $J$ Comp Neurol, 301, 365-381.

Altman, J. \& Das, G.D. (1965) Autoradiographic and histological evidence of postnatal hippocampal neurogenesis in rats. J Comp Neurol, 124, 319-335.

Bengzon, J., Kokaia, Z., Elmer, E., Nanobashvili, A., Kokaia, M. \& Lindvall, O. (1997) Apoptosis and proliferation of dentate gyrus neurons after single and intermittent limbic seizures. Proc Natl Acad Sci U S A, 94, 10432-10437.

Bjornebekk, A., Mathe, A.A. \& Brene, S. (2006) Running has differential effects on NPY, opiates, and cell proliferation in an animal model of depression and controls. Neuropsychopharmacology, 31, 256-264.

Bouchard, P., Maurice, T., St-Pierre, S., Privat, A. \& Quirion, R. (1997) Neuropeptide Y and the calcitonin gene-related peptide attenuate learning impairments induced by MK-801 via a sigma receptor-related mechanism. Eur J Neurosci, 9, 2142-2151.

Brezun, J.M. \& Daszuta, A. (2000) Serotonin may stimulate granule cell proliferation in the adult hippocampus, as observed in rats grafted with foetal raphe neurons. Eur J Neurosci, 12, 391-396.

Butovsky, O., Talpalar, A.E., Ben-Yaakov, K. \& Schwartz, M. (2005) Activation of microglia by aggregated beta-amyloid or lipopolysaccharide impairs MHC-II expression and renders them cytotoxic whereas IFN-gamma and IL-4 render them protective. Mol Cell Neurosci, 29, 381-393.

Butovsky, O., Ziv, Y., Schwartz, A., Landa, G., Talpalar, A.E., Pluchino, S., Martino, G. \& Schwartz, M. (2006) Microglia activated by IL-4 or IFN-gamma differentially induce neurogenesis and oligodendrogenesis from adult stem/progenitor cells. Mol Cell Neurosci, 31, 149-160.

Caberlotto, L., Jimenez, P., Overstreet, D.H., Hurd, Y.L., Mathe, A.A. \& Fuxe, K. (1999) Alterations in neuropeptide Y levels and Y1 binding sites in the Flinders Sensitive Line rats, a genetic animal model of depression. Neurosci Lett, 265, 191-194.

Cameron, H.A. \& Gould, E. (1994) Adult neurogenesis is regulated by adrenal steroids in the dentate gyrus. Neuroscience, 61, 203-209.

Cameron, H.A., McEwen, B.S. \& Gould, E. (1995) Regulation of adult neurogenesis by excitatory input and NMDA receptor activation in the dentate gyrus. $J$ Neurosci, 15, 4687-4692. 
Cameron, H.A. \& McKay, R.D. (2001) Adult neurogenesis produces a large pool of new granule cells in the dentate gyrus. J Comp Neurol, 435, 406-417.

Carvajal, C.C., Vercauteren, F., Dumont, Y., Michalkiewicz, M. \& Quirion, R. (2004) Aged neuropeptide $Y$ transgenic rats are resistant to acute stress but maintain spatial and non-spatial learning. Behav Brain Res, 153, 471-480.

Causing, C.G., Makus, K.D., Ma, Y., Miller, F.D. \& Colmers, W.F. (1996) Selective upregulation of T alpha 1 alpha-tubulin and neuropeptide Y mRNAs after intermittent excitatory stimulation in adult rat hippocampus in vivo. J Comp Neurol, 367, 132-146.

Chen, G., Rajkowska, G., Du, F., Seraji-Bozorgzad, N. \& Manji, H.K. (2000) Enhancement of hippocampal neurogenesis by lithium. J Neurochem, 75, 17291734.

Ciaroni, S., Cecchini, T., Ferri, P., Ambrogini, P., Cuppini, R., Riccio, M., Lombardelli, G., Papa, S. \& Del Grande, P. (2002) Impairment of neural precursor proliferation increases survival of cell progeny in the adult rat dentate gyrus. Mech Ageing Dev, 123, 1341-1352.

Colmers, W.F. \& Bleakman, D. (1994) Effects of neuropeptide Y on the electrical properties of neurons. Trends Neurosci, 17, 373-379.

Covolan, L., Ribeiro, L.T., Longo, B.M. \& Mello, L.E. (2000) Cell damage and neurogenesis in the dentate granule cell layer of adult rats after pilocarpine- or kainate-induced status epilepticus. Hippocampus, 10, 169-180.

Curtis, M.A., Kam, M., Nannmark, U., Anderson, M.F., Axell, M.Z., Wikkelso, C., Holtas, S., van Roon-Mom, W.M., Bjork-Eriksson, T., Nordborg, C., Frisen, J., Dragunow, M., Faull, R.L. \& Eriksson, P.S. (2007) Human neuroblasts migrate to the olfactory bulb via a lateral ventricular extension. Science, 315, 1243-1249.

D'Sa, C. \& Duman, R.S. (2002) Antidepressants and neuroplasticity. Bipolar Disord, 4, 183-194.

de Bono, M. \& Bargmann, C.I. (1998) Natural variation in a neuropeptide Y receptor homolog modifies social behavior and food response in C. elegans. Cell, 94, 679689.

Deisseroth, K., Singla, S., Toda, H., Monje, M., Palmer, T.D. \& Malenka, R.C. (2004) Excitation-neurogenesis coupling in adult neural stem/progenitor cells. Neuron, 42, 535-552.

Deller, T. \& Leranth, C. (1990) Synaptic connections of neuropeptide Y (NPY) immunoreactive neurons in the hilar area of the rat hippocampus. J. Comp. Neurol., 300, 433-447.

Doetsch, F., Caille, I., Lim, D.A., Garcia-Verdugo, J.M. \& Alvarez-Buylla, A. (1999) Subventricular zone astrocytes are neural stem cells in the adult mammalian brain. Cell, 97, 703-716.

Drapeau, E., Mayo, W., Aurousseau, C., Le Moal, M., Piazza, P.V. \& Abrous, D.N. (2003) Spatial memory performances of aged rats in the water maze predict levels of hippocampal neurogenesis. Proc Natl Acad Sci U S A, 100, 14385-14390.

Eichenbaum, H. (1997) Declarative memory: insights from cognitive neurobiology. Annu Rev Psychol, 48, 547-572. 
Ekdahl, C.T., Claasen, J.H., Bonde, S., Kokaia, Z. \& Lindvall, O. (2003) Inflammation is detrimental for neurogenesis in adult brain. Proc Natl Acad Sci US A, 100, 13632-13637.

Erickson, J.C., Clegg, K.E. \& Palmiter, R.D. (1996) Sensitivity to leptin and susceptibility to seizures of mice lacking neuropeptide Y. Nature, 381, 415-421.

Eriksson, P.S., Perfilieva, E., Bjork-Eriksson, T., Alborn, A.M., Nordborg, C., Peterson, D.A. \& Gage, F.H. (1998) Neurogenesis in the adult human hippocampus. Nat Med, 4, 1313-1317.

Fabry, M., Langer, M., Rothen-Rutishauser, B., Wunderli-Allenspach, H., Hocker, H. \& Beck-Sickinger, A.G. (2000) Monitoring of the internalization of neuropeptide Y on neuroblastoma cell line SK-N-MC. Eur J Biochem, 267, 5631-5637.

Ferland, R.J., Gross, R.A. \& Applegate, C.D. (2002) Increased mitotic activity in the dentate gyrus of the hippocampus of adult $\mathrm{C} 57 \mathrm{BL} / 6 \mathrm{~J}$ mice exposed to the flurothyl kindling model of epileptogenesis. Neuroscience, 115, 669-683.

Flood, J.F., Hernandez, E.N. \& Morley, J.E. (1987) Modulation of memory processing by neuropeptide Y. Brain Res, 421, 280-290.

Flood, J.F. \& Morley, J.E. (1989) Dissociation of the effects of neuropeptide Y on feeding and memory: evidence for pre- and postsynaptic mediation. Peptides, 10, 963-966.

Freund, T.F. \& Buzsaki, G. (1996) Interneurons of the hippocampus. Hippocampus, 6 , $347-470$.

Gage, F.H. (2002) Neurogenesis in the adult brain. J Neurosci, 22, 612-613.

Ge, S., Goh, E.L., Sailor, K.A., Kitabatake, Y., Ming, G.L. \& Song, H. (2006) GABA regulates synaptic integration of newly generated neurons in the adult brain. Nature, 439, 589-593.

Ge, S., Pradhan, D.A., Ming, G.L. \& Song, H. (2007) GABA sets the tempo for activitydependent adult neurogenesis. Trends Neurosci, 30, 1-8.

Gould, E., Beylin, A., Tanapat, P., Reeves, A. \& Shors, T.J. (1999) Learning enhances adult neurogenesis in the hippocampal formation. Nat Neurosci, 2, 260-265.

Gould, E., McEwen, B.S., Tanapat, P., Galea, L.A. \& Fuchs, E. (1997) Neurogenesis in the dentate gyrus of the adult tree shrew is regulated by psychosocial stress and NMDA receptor activation. $J$ Neurosci, 17, 2492-2498.

Gray, W.P. \& Sundstrom, L.E. (1998) Kainic acid increases the proliferation of granule cell progenitors in the dentate gyrus of the adult rat. Brain Res, 790, 52-59.

Gruber, B., Greber, S., Rupp, E. \& Sperk, G. (1994) Differential NPY mRNA expression in granule cells and interneurons of the rat dentate gyrus after kainic acid injection. Hippocampus, 4, 474-482.

Hack, M.A., Saghatelyan, A., de Chevigny, A., Pfeifer, A., Ashery-Padan, R., Lledo, P.M. \& Gotz, M. (2005) Neuronal fate determinants of adult olfactory bulb neurogenesis. Nat Neurosci, 8, 865-872.

Hansel, D.E., Eipper, B.A. \& Ronnett, G.V. (2001a) Neuropeptide Y functions as a neuroproliferative factor. Nature, 410, 940-944.

Hansel, D.E., Eipper, B.A. \& Ronnett, G.V. (2001b) Regulation of olfactory neurogenesis by amidated neuropeptides. J Neurosci Res, 66, 1-7.

Hastings, N.B. \& Gould, E. (1999) Rapid extension of axons into the CA3 region by adult-generated granule cells. J Comp Neurol, 413, 146-154. 
Heilig, M. (2004) The NPY system in stress, anxiety and depression. Neuropeptides, 38, 213-224.

Heilig, M., Soderpalm, B., Engel, J.A. \& Widerlov, E. (1989) Centrally administered neuropeptide Y (NPY) produces anxiolytic-like effects in animal anxiety models. Psychopharmacology (Berl), 98, 524-529.

Heilig, M., Wahlestedt, C., Ekman, R. \& Widerlov, E. (1988) Antidepressant drugs increase the concentration of neuropeptide Y (NPY)-like immunoreactivity in the rat brain. Eur J Pharmacol, 147, 465-467.

Higuchi, H., Yang, H.Y. \& Costa, E. (1988) Age-related bidirectional changes in neuropeptide Y peptides in rat adrenal glands, brain, and blood. J Neurochem, 50, 1879-1886.

Hokfelt, T., Johansson, O. \& Goldstein, M. (1984) Chemical anatomy of the brain. Science, 225, 1326-1334.

Howell, O.W., Doyle, K., Goodman, J.H., Scharfman, H.E., Herzog, H., Pringle, A., Beck-Sickinger, A.G. \& Gray, W.P. (2005) Neuropeptide Y stimulates neuronal precursor proliferation in the post-natal and adult dentate gyrus. $J$ Neurochem, 93 , 560-570.

Howell, O.W., Scharfman, H.E., Herzog, H., Sundstrom, L.E., Beck-Sickinger, A. \& Gray, W.P. (2003) Neuropeptide Y is neuroproliferative for post-natal hippocampal precursor cells. J Neurochem, 86, 646-659.

Howell, O.W., Silva, S., Scharfman, H.E., Sosunov, A.A., Zaben, M., Shatya, A., McKhann, G., 2nd, Herzog, H., Laskowski, A. \& Gray, W.P. (2007)

Neuropeptide $\mathrm{Y}$ is important for basal and seizure-induced precursor cell proliferation in the hippocampus. Neurobiol Dis, 26, 174-188.

Husum, H. \& Mathe, A.A. (2002) Early life stress changes concentrations of neuropeptide $\mathrm{Y}$ and corticotropin-releasing hormone in adult rat brain. Lithium treatment modifies these changes. Neuropsychopharmacology, 27, 756-764.

Husum, H., Mikkelsen, J.D., Hogg, S., Mathe, A.A. \& Mork, A. (2000) Involvement of hippocampal neuropeptide $\mathrm{Y}$ in mediating the chronic actions of lithium, electroconvulsive stimulation and citalopram. Neuropharmacology, 39, 14631473.

Huttmann, K., Sadgrove, M., Wallraff, A., Hinterkeuser, S., Kirchhoff, F., Steinhauser, C. \& Gray, W.P. (2003) Seizures preferentially stimulate proliferation of radial glia-like astrocytes in the adult dentate gyrus: functional and immunocytochemical analysis. Eur J Neurosci, 18, 2769-2778.

Jacobs, B.L., Praag, H. \& Gage, F.H. (2000) Adult brain neurogenesis and psychiatry: a novel theory of depression. Mol Psychiatry, 5, 262-269.

Jessberger, S., Romer, B., Babu, H. \& Kempermann, G. (2005) Seizures induce proliferation and dispersion of doublecortin-positive hippocampal progenitor cells. Exp Neurol, 196, 342-351.

Jessberger, S., Zhao, C., Toni, N., Clemenson, G.D., Jr., Li, Y. \& Gage, F.H. (2007)

Seizure-associated, aberrant neurogenesis in adult rats characterized with retrovirus-mediated cell labeling. J Neurosci, 27, 9400-9407.

Jiang, W., Wan, Q., Zhang, Z.J., Wang, W.D., Huang, Y.G., Rao, Z.R. \& Zhang, X. (2003) Dentate granule cell neurogenesis after seizures induced by pentylenetrazol in rats. Brain Res, 977, 141-148. 
Kalra, S.P. \& Kalra, P.S. (2004) NPY and cohorts in regulating appetite, obesity and metabolic syndrome: beneficial effects of gene therapy. Neuropeptides, 38, 201211.

Karishma, K.K. \& Herbert, J. (2002) Dehydroepiandrosterone (DHEA) stimulates neurogenesis in the hippocampus of the rat, promotes survival of newly formed neurons and prevents corticosterone-induced suppression. Eur J Neurosci, 16, 445-453.

Karlsson, R.M., Choe, J.S., Cameron, H.A., Thorsell, A., Crawley, J.N., Holmes, A. \& Heilig, M. (2007) The neuropeptide Y Y1 receptor subtype is necessary for the anxiolytic-like effects of neuropeptide $Y$, but not the antidepressant-like effects of fluoxetine, in mice. Psychopharmacology (Berl).

Kastin, A.J. \& Akerstrom, V. (1999) Nonsaturable entry of neuropeptide Y into brain. Am J Physiol, 276, E479-482.

Kempermann, G., Jessberger, S., Steiner, B. \& Kronenberg, G. (2004) Milestones of neuronal development in the adult hippocampus. Trends Neurosci, 27, 447-452.

Kempermann, G., Kuhn, H.G. \& Gage, F.H. (1997) More hippocampal neurons in adult mice living in an enriched environment. Nature, 386, 493-495.

Kohler, C., Eriksson, L., Davies, S. \& Chan-Palay, V. (1986) Neuropeptide Y Innervation of the Hippocampal Region in the Rat and Monkey Brain. The Journal of Comparative Neurology, 244, 384-400.

Kopp, J., Xu, Z.Q., Zhang, X., Pedrazzini, T., Herzog, H., Kresse, A., Wong, H., Walsh, J.H. \& Hokfelt, T. (2002a) Expression of the neuropeptide Y Y1 receptor in the $\mathrm{CNS}$ of rat and of wild-type and Y1 receptor knock-out mice. Focus on immunohistochemical localization. Neuroscience, 111, 443-532.

Kopp, J., Xu, Z.Q., Zhang, X., Pedrazzini, T., Herzog, H., Kresse, A., Wong, H., Walsh, J.H. \& Hokfelt, T. (2002b) Expression of the neuropeptide Y Y1 receptor in the CNS of rat and of wild-type and Y1 receptor knock-out mice. Focus on immunohistochemical localization(1). Neuroscience, 111, 443-532.

Krsmanovic, L.Z., Stojilkovic, S.S., Mertz, L.M., Tomic, M. \& Catt, K.J. (1993) Expression of gonadotropin-releasing hormone receptors and autocrine regulation of neuropeptide release in immortalized hypothalamic neurons. Proc Natl Acad Sci US A, 90, 3908-3912.

Larhammar, D. (1996) Evolution of neuropeptide Y, peptide YY and pancreatic polypeptide. Regul Pept, 62, 1-11.

Laskowski, A., Howell, O.W., Sosunov, A.A., McKhann, G. \& Gray, W.P. (2007) NPY mediates basal and seizure-induced proliferation in the subcallosal zone. Neuroreport, 18, 1005-1008.

Lemaire, V., Koehl, M., Le Moal, M. \& Abrous, D.N. (2000) Prenatal stress produces learning deficits associated with an inhibition of neurogenesis in the hippocampus. Proc Natl Acad Sci U S A, 97, 11032-11037.

Lendahl, U., Zimmerman, L.B. \& McKay, R.D. (1990) CNS stem cells express a new class of intermediate filament protein. Cell, 60, 585-595.

Levison, S.W. \& Goldman, J.E. (1993) Both oligodendrocytes and astrocytes develop from progenitors in the subventricular zone of postnatal rat forebrain. Neuron, 10, 201-212. 
Levison, S.W., Young, G.M. \& Goldman, J.E. (1999) Cycling cells in the adult rat neocortex preferentially generate oligodendroglia. J Neurosci Res, 57, 435-446.

Li, B.S., Ma, W., Zhang, L., Barker, J.L., Stenger, D.A. \& Pant, H.C. (2001) Activation of phosphatidylinositol-3 kinase (PI-3K) and extracellular regulated kinases (Erk1/2) is involved in muscarinic receptor-mediated DNA synthesis in neural progenitor cells. J Neurosci, 21, 1569-1579.

Liu, X., Wang, Q., Haydar, T.F. \& Bordey, A. (2005) Nonsynaptic GABA signaling in postnatal subventricular zone controls proliferation of GFAP-expressing progenitors. Nat Neurosci, 8, 1179-1187.

Lois, C. \& Alvarez-Buylla, A. (1993) Proliferating subventricular zone cells in the adult mammalian forebrain can differentiate into neurons and glia. Proc Natl Acad Sci $U S A, 90,2074-2077$.

Lopez-Ilasaca, M. (1998) Signaling from G-protein-coupled receptors to mitogenactivated protein (MAP)-kinase cascades. Biochem Pharmacol, 56, 269-277.

Lundberg, J.M., Martinsson, A., Hemsen, A., Theodorsson-Norheim, E., Svedenhag, J., Ekblom, B. \& Hjemdahl, P. (1985) Co-release of neuropeptide Y and catecholamines during physical exercise in man. Biochem Biophys Res Commun, 133, 30-36.

Madsen, T.M., Treschow, A., Bengzon, J., Bolwig, T.G., Lindvall, O. \& Tingstrom, A. (2000) Increased neurogenesis in a model of electroconvulsive therapy. Biol Psychiatry, 47, 1043-1049.

Malberg, J.E., Eisch, A.J., Nestler, E.J. \& Duman, R.S. (2000) Chronic antidepressant treatment increases neurogenesis in adult rat hippocampus. $J$ Neurosci, 20, 91049110.

Markakis, E.A. \& Gage, F.H. (1999) Adult-generated neurons in the dentate gyrus send axonal projections to field CA 3 and are surrounded by synaptic vesicles. $J$ Comp Neurol, 406, 449-460.

Marksteiner, J., Ortler, M., Bellman, R. \& Sperk, G. (1990) Neuropeptide Y biosynthesis is markedly induced in mossy fibers during temporal lobe epilepsy of the rat. Neurosci. Lett., 112, 143-148.

Marksteiner, J., Sperk, G. \& Maas, D. (1989) Differential increases in brain levels of neuropeptide $Y$ and vasoactive intestinal polypeptide after kainic acid-induced seizures in the rat. Naunyn Schmiedebergs Arch Pharmacol, 339, 173-177.

Mazarati, A., Lu, X., Kilk, K., Langel, U., Wasterlain, C. \& Bartfai, T. (2004) Galanin type 2 receptors regulate neuronal survival, susceptibility to seizures and seizureinduced neurogenesis in the dentate gyrus. Eur J Neurosci, 19, 3235-3244.

McCarthy, J.B., Walker, M., Pierce, J., Camp, P. \& White, J.D. (1998) Biosynthesis and Metabolism of Native and Oxidized Neuropeptide Y in the Hippocampal Mossy Fiber System. Journal of Neurochemistry, 1950-1963.

Menn, B., Garcia-Verdugo, J.M., Yaschine, C., Gonzalez-Perez, O., Rowitch, D. \& Alvarez-Buylla, A. (2006) Origin of oligodendrocytes in the subventricular zone of the adult brain. $J$ Neurosci, 26, 7907-7918.

Merkle, F.T., Mirzadeh, Z. \& Alvarez-Buylla, A. (2007) Mosaic organization of neural stem cells in the adult brain. Science, 317, 381-384.

Mikkelsen, J.D., Woldbye, D., Kragh, J., Larsen, P.J. \& Bolwig, T.G. (1994) Electroconvulsive shocks increase the expression of neuropeptide Y (NPY) 
mRNA in the piriform cortex and the dentate gyrus. Brain Res Mol Brain Res, 23, 317-322.

Milner, T.A. \& Veznedaroglu, E. (1992) Ultrastructural Localization of Neuropeptide Ylike Immunoreactivity in the Rat Hippocampal Formation. Hippocampus, 2, 107126.

Mitchell, J., Cook, I. \& Hervey, V. (1997) Effect of seizures on hippocampal peptidergic neurons. Neuropathology and Applied Neurobiology, 23, 299-306.

Modigh, K. (1976) Long-term effects of electroconvulsive shock therapy on synthesis, turnover and uptake of brain monoamines. Psychopharmacology (Berl), 49, 179185.

Mohapel, P., Leanza, G., Kokaia, M. \& Lindvall, O. (2005) Forebrain acetylcholine regulates adult hippocampal neurogenesis and learning. Neurobiol Aging, 26, 939946.

Monje, M.L., Toda, H. \& Palmer, T.D. (2003) Inflammatory blockade restores adult hippocampal neurogenesis. Science, 302, 1760-1765.

Morgan, C.A., 3rd, Rasmusson, A.M., Wang, S., Hoyt, G., Hauger, R.L. \& Hazlett, G. (2002) Neuropeptide-Y, cortisol, and subjective distress in humans exposed to acute stress: replication and extension of previous report. Biol Psychiatry, 52, $136-142$.

Morgan, C.A., 3rd, Wang, S., Southwick, S.M., Rasmusson, A., Hazlett, G., Hauger, R.L. \& Charney, D.S. (2000) Plasma neuropeptide-Y concentrations in humans exposed to military survival training. Biol Psychiatry, 47, 902-909.

Nakagawa, E., Aimi, Y., Yasuhara, O., Tooyama, I., Shimada, M., McGeer, P.L. \& Kimura, H. (2000) Enhancement of progenitor cell division in the dentate gyrus triggered by initial limbic seizures in rat models of epilepsy. Epilepsia, 41, 10-18.

O'Kusky, J.R., Ye, P. \& D'Ercole, A.J. (2000) Insulin-like growth factor-I promotes neurogenesis and synaptogenesis in the hippocampal dentate gyrus during postnatal development. J Neurosci, 20, 8435-8442.

Overstreet Wadiche, L., Bromberg, D.A., Bensen, A.L. \& Westbrook, G.L. (2005) GABAergic signaling to newborn neurons in dentate gyrus. Journal of neurophysiology, 94, 4528-4532.

Overstreet-Wadiche, L.S., Bromberg, D.A., Bensen, A.L. \& Westbrook, G.L. (2006) Seizures accelerate functional integration of adult-generated granule cells. $J$ Neurosci, 26, 4095-4103.

Palmer, T.D., Takahashi, J. \& Gage, F.H. (1997) The adult rat hippocampus contains primordial neural stem cells. Mol Cell Neurosci, 8, 389-404.

Parent, J.M. (2002) The role of seizure-induced neurogenesis in epileptogenesis and brain repair. Epilepsy Res, 50, 179-189.

Parent, J.M., Elliott, R.C., Pleasure, S.J., Barbaro, N.M. \& Lowenstein, D.H. (2006) Aberrant seizure-induced neurogenesis in experimental temporal lobe epilepsy. Ann Neurol, 59, 81-91.

Parent, J.M., Valentin, V.V. \& Lowenstein, D.H. (2002) Prolonged seizures increase proliferating neuroblasts in the adult rat subventricular zone-olfactory bulb pathway. J Neurosci, 22, 3174-3188.

Parent, J.M., Yu, T.W., Leibowitz, R.T., Geschwind, D.H., Sloviter, R.S. \& Lowenstein, D.H. (1997) Dentate granule cell neurogenesis is increased by seizures and 
contributes to aberrant network reorganization in the adult rat hippocampus. $J$ Neurosci, 17, 3727-3738.

Parker, R.M.C. \& Herzog, H. (1999) Regional distribution of Y-receptor subtype mRNAs in rat brain. European Journal of Neuroscience, 11, 1431-1448.

Pedrazzini, T., Seydoux, J., Kunstner, P., Aubert, J.F., Grouzmann, E., Beermann, F. \& Brunner, H.R. (1998) Cardiovascular response, feeding behavior and locomotor activity in mice lacking the NPY Y1 receptor. Nat Med, 4, 722-726.

Pernow, J., Lundberg, J.M., Kaijser, L., Hjemdahl, P., Theodorsson-Norheim, E., Martinsson, A. \& Pernow, B. (1986) Plasma neuropeptide Y-like immunoreactivity and catecholamines during various degrees of sympathetic activation in man. Clin Physiol, 6, 561-578.

Pickel, V.M., Chan, J., Veznedaroglu, E. \& Milner, T.A. (1995) Neuropeptide Y and dynorphin-immunoreactive large dense-core vesicles are strategically localized for presynaptic modulation in the hippocampal formation and substantia nigra. Synapse, 19, 160-169.

Prickaerts, J., Koopmans, G., Blokland, A. \& Scheepens, A. (2004) Learning and adult neurogenesis: survival with or without proliferation? Neurobiol Learn Mem, 81, $1-11$.

Radley, J.J. \& Jacobs, B.L. (2003) Pilocarpine-induced status epilepticus increases cell proliferation in the dentate gyrus of adult rats via a 5-HT1A receptor-dependent mechanism. Brain Res, 966, 1-12.

Redrobe, J.P., Dumont, Y., Fournier, A. \& Quirion, R. (2002) The neuropeptide Y (NPY) Y1 receptor subtype mediates NPY-induced antidepressant-like activity in the mouse forced swimming test. Neuropsychopharmacology, 26, 615-624.

Redrobe, J.P., Dumont, Y., Herzog, H. \& Quirion, R. (2004) Characterization of neuropeptide $\mathrm{Y}, \mathrm{Y}(2)$ receptor knockout mice in two animal models of learning and memory processing. J Mol Neurosci, 22, 159-166.

Redrobe, J.P., Dumont, Y., St-Pierre, J.A. \& Quirion, R. (1999) Multiple receptors for neuropeptide $\mathrm{Y}$ in the hippocampus: putative roles in seizures and cognition. Brain Res, 848, 153-166.

Sajdyk, T.J., Vandergriff, M.G. \& Gehlert, D.R. (1999) Amygdalar neuropeptide Y Y1 receptors mediate the anxiolytic-like actions of neuropeptide $\mathrm{Y}$ in the social interaction test. Eur J Pharmacol, 368, 143-147.

Santarelli, L., Saxe, M., Gross, C., Surget, A., Battaglia, F., Dulawa, S., Weisstaub, N., Lee, J., Duman, R., Arancio, O., Belzung, C. \& Hen, R. (2003) Requirement of hippocampal neurogenesis for the behavioral effects of antidepressants. Science, 301, 805-809.

Scharfman, H.E., Goodman, J.H. \& Sollas, A.L. (2000) Granule-like neurons at the hilar/CA3 border after status epilepticus and their synchrony with area CA3 pyramidal cells: functional implications of seizure-induced neurogenesis. $J$ Neurosci, 20, 6144-6158.

Scharfman, H.E. \& Gray, W.P. (2006) Plasticity of neuropeptide Y in the dentate gyrus after seizures, and its relevance to seizure-induced neurogenesis. Exs, 193-211.

Schlessinger, A.R., Cowan, W.M. \& Gottlieb, D.I. (1975) An autoradiographic study of the time of origin and the pattern of granule cell migration in the dentate gyrus of the rat. J Comp Neurol, 159, 149-175. 
Seaberg, R.M. \& van der Kooy, D. (2002) Adult rodent neurogenic regions: the ventricular subependyma contains neural stem cells, but the dentate gyrus contains restricted progenitors. J Neurosci, 22, 1784-1793.

Seki, T. \& Arai, Y. (1999) Temporal and spacial relationships between PSA-NCAMexpressing, newly generated granule cells, and radial glia-like cells in the adult dentate gyrus. J Comp Neurol, 410, 503-513.

Seri, B., Garcia-Verdugo, J.M., Collado-Morente, L., McEwen, B.S. \& Alvarez-Buylla, A. (2004) Cell types, lineage, and architecture of the germinal zone in the adult dentate gyrus. J Comp Neurol, 478, 359-378.

Seri, B., Garcia-Verdugo, J.M., McEwen, B.S. \& Alvarez-Buylla, A. (2001) Astrocytes give rise to new neurons in the adult mammalian hippocampus. J Neurosci, 21, 7153-7160.

Seri, B., Herrera, D.G., Gritti, A., Ferron, S., Collado, L., Vescovi, A., Garcia-Verdugo, J.M. \& Alvarez-Buylla, A. (2006) Composition and organization of the SCZ: a large germinal layer containing neural stem cells in the adult mammalian brain. Cereb Cortex, 16 Suppl 1, i103-111.

Shapiro, L.A., Korn, M.J., Shan, Z. \& Ribak, C.E. (2005) GFAP-expressing radial glialike cell bodies are involved in a one-to-one relationship with doublecortinimmunolabeled newborn neurons in the adult dentate gyrus. Brain Res, 1040, 8191.

Shors, T.J. (2004) Memory traces of trace memories: neurogenesis, synaptogenesis and awareness. Trends Neurosci, 27, 250-256.

Shors, T.J., Miesegaes, G., Beylin, A., Zhao, M., Rydel, T. \& Gould, E. (2001) Neurogenesis in the adult is involved in the formation of trace memories. Nature, 410, 372-376.

Snyder, J.S., Kee, N. \& Wojtowicz, J.M. (2001) Effects of adult neurogenesis on synaptic plasticity in the rat dentate gyrus. $J$ Neurophysiol, 85, 2423-2431.

Sokolowski, M.B. (2003) NPY and the regulation of behavioral development. Neuron, 39, 6-8.

Sperk, G., Marksteiner, J., Gurber, B., Bellmann, R., Mahata, M. \& Ortler, M. (1992) Functional Changes in Neuropeptide Y- and Somatostatin-Containing Neurons Induced By Limbic Seizures in the Rat. Neuroscience, 50, 831-846.

Thiele, T.E., Sparta, D.R., Hayes, D.M. \& Fee, J.R. (2004) A role for neuropeptide Y in neurobiological responses to ethanol and drugs of abuse. Neuropeptides, 38, 235 243.

Thorsell, A., Michalkiewicz, M., Dumont, Y., Quirion, R., Caberlotto, L., Rimondini, R., Mathe, A.A. \& Heilig, M. (2000) Behavioral insensitivity to restraint stress, absent fear suppression of behavior and impaired spatial learning in transgenic rats with hippocampal neuropeptide Y overexpression. Proc Natl Acad Sci U S A, 97, 12852-12857.

Tozuka, Y., Fukuda, S., Namba, T., Seki, T. \& Hisatsune, T. (2005) GABAergic excitation promotes neuronal differentiation in adult hippocampal progenitor cells. Neuron, 47, 803-815.

Ubink, R., Calza, L. \& Hokfelt, T. (2003) "Neuro"-peptides in glia: focus on NPY and galanin. Trends in Neuroscience, 26, 604-609. 
Vallieres, L., Campbell, I.L., Gage, F.H. \& Sawchenko, P.E. (2002) Reduced hippocampal neurogenesis in adult transgenic mice with chronic astrocytic production of interleukin-6. J Neurosci, 22, 486-492.

Van der Borght, K., Mulder, J., Keijser, J.N., Eggen, B.J., Luiten, P.G. \& Van der Zee, E.A. (2005) Input from the medial septum regulates adult hippocampal neurogenesis. Brain research bulletin, 67, 117-125.

van Praag, H., Kempermann, G. \& Gage, F.H. (1999) Running increases cell proliferation and neurogenesis in the adult mouse dentate gyrus. Nat Neurosci, 2, 266-270.

van Praag, H., Schinder, A.F., Christie, B.R., Toni, N., Palmer, T.D. \& Gage, F.H. (2002) Functional neurogenesis in the adult hippocampus. Nature, 415, 1030-1034.

Vezzani, A., Monhemius, R., Tutka, P., Milani, R. \& Samanin, R. (1996) Functional Activation of Somatostatin- and Neuropeptide Y-Containing Neurons in the Entorhinal Cortex of Chronically Epileptic Rats. Neuroscience, 75, 551-557.

Vezzani, A., Ravizza, T., Moneta, D., Conti, M., Borroni, A., Rizzi, M., Samanin, R. \& Maj, R. (1999a) Brain-Derived Neurotrophic Factor Immunoreactivity in the Limbic System of Rats After Acute Seizures and During Spontaneous Convulsons: Temporal Evolution of Changes As Compared to Neuropeptide Y. Neuroscience, 90, 1445-1461.

Vezzani, A. \& Sperk, G. (2004) Overexpression of NPY and Y2 receptors in epileptic brain tissue: an endogenous neuroprotective mechanism in temporal lobe epilepsy? Neuropeptides, 38, 245-252.

Vezzani, A., Sperk, G. \& Colmers, W.F. (1999b) Neuropeptide Y: emerging evidence for a functional role in seizure modulation. Trends Neurosci, 22, 25-30.

Wahlestedt, C., Pich, E.M., Koob, G.F., Yee, F. \& Heilig, M. (1993) Modulation of anxiety and neuropeptide $\mathrm{Y}-\mathrm{Y} 1$ receptors by antisense oligodeoxynucleotides. Science, 259, 528-531.

Wang, D.D., Krueger, D.D. \& Bordey, A. (2003) GABA depolarizes neuronal progenitors of the postnatal subventricular zone via GABAA receptor activation. The Journal of physiology, 550, 785-800.

Wang, L.P., Kempermann, G. \& Kettenmann, H. (2005) A subpopulation of precursor cells in the mouse dentate gyrus receives synaptic GABAergic input. Mol Cell Neurosci, 29, 181-189.

Waschek, J.A., Lelievre, V., Bravo, D.T., Nguyen, T. \& Muller, J.M. (1997) Retinoic acid regulation of the VIP and PACAP autocrine ligand and receptor system in human neuroblastoma cell lines. Peptides, 18, 835-841.

Westrin, A., Ekman, R. \& Traskman-Bendz, L. (1999) Alterations of corticotropin releasing hormone (CRH) and neuropeptide Y (NPY) plasma levels in mood disorder patients with a recent suicide attempt. Eur Neuropsychopharmacol, 9, 205-211.

Wettstein, J.G., Earley, B. \& Junien, J.L. (1995) Central nervous system pharmacology of neuropeptide Y. Pharmacology \& therapeutics, 65, 397-414.

Wu, Q., Wen, T., Lee, G., Park, J.H., Cai, H.N. \& Shen, P. (2003) Developmental control of foraging and social behavior by the Drosophila neuropeptide Y-like system. Neuron, 39, 147-161.

Xu, Z.Q., Shi, T.J. \& Hokfelt, T. (1998) Galanin/GMAP- and NPY-like immunoreactivities in locus coeruleus and noradrenergic nerve terminals in the 
hippocampal formation and cortex with notes on the galanin-R1 and -R2 receptors. J Comp Neurol, 392, 227-251.

Yoshimura, S., Takagi, Y., Harada, J., Teramoto, T., Thomas, S.S., Waeber, C., Bakowska, J.C., Breakefield, X.O. \& Moskowitz, M.A. (2001) FGF-2 regulation of neurogenesis in adult hippocampus after brain injury. Proc Natl Acad Sci US $A$, 98, 5874-5879.

Ziv, Y., Ron, N., Butovsky, O., Landa, G., Sudai, E., Greenberg, N., Cohen, H., Kipnis, J. \& Schwartz, M. (2006) Immune cells contribute to the maintenance of neurogenesis and spatial learning abilities in adulthood. Nat Neurosci, 9, 268-275. 
Figure Legends

Figure 1.

Schematic diagram of a cross section of adult hippocampus showing a granule cell neuron (Black) with its dendrites extending up to the hippocampal fissure (HF), its cell body in the granule cell layer (GCL) and its axon or mossy fiber extending out into area CA3 of the hippocampus. The neurogenic niche that produces granule cell neurons lies between the GCL and the hilus and is termed the subgranular zone (SGZ). Interneurons (IN) that release neuropeptides are located in the SGZ and hilus. The other stem/precursor niches in or around the hippocampus are the subcallosal zone (SCZ) lying in the potential space between the hippocampus and overlying corpus callosum and the caudal subventricular zone (cSVZ) lying on the ventricular surface of the dorsal hippocampus.

Figure 2 .

Schematic diagram of the different precursor/progenitor cells in the subgranular zone (SGZ) and their phases of maturation, together with the markers expressed and the timescale of their differentiation. Bold lettering indicates positive immunostaining. An attempted translation between different classifications as detailed in the main text is also shown.

Figure 3.

NPY enhances the total number of cells, BrdU positive cells, $\beta$ tubulin positive cells and nestin immuno-positive cells with time in culture. 
Hippocampal cell cultures were grown for the indicated number of days in standard control conditions, or in the presence of $1 \mathrm{mM}$ NPY. BrdU was added for the final $24 \mathrm{hrs}$ of each time-point. (A), total cell counts increase under standard conditions, and are further significantly increased in the presence of NPY. (B), the number of BrdU incorporating cells is increased between day 1 and 7 in control conditions, and are increased relative to controls at each of day 3, 5, 7 in the presence of NPY. (C), nestin counts increase with days in vitro, and are significantly different from controls at days 3 , $5 \&$ 7. (D), ß-tubulin counts are maximal at day 3 , and in control and NPY conditions fall with time in culture. (Comparing control counts to control counts at day $1,+, \mathrm{p}<0.05,++$, $\mathrm{p}<0.01$; Comparing NPY to respective time point controls; **, $\mathrm{p}<0.01$ ). Representative phase contrast images of cells cultured in 1mM NPY. Cells were imaged at 3, 5 and 7 div. Note the large increase in cell numbers, and in particular the high proportion of immature, phase bright cells seen on days $5 \& 7$. It should be noted that other and often diverse cell types are present on all days. Scale bar; $100 \mu \mathrm{m}$. (F) NPY does not affect cell survival. Cells were cultured in control or 1mM NPY conditions for the indicated times. Cell death was assessed by quantifying chromatin condensation (ie: cells displaying a pyknotic nucleus) and expressed as a proportion of total cells counted per field of view. Cell death was similar under control or NPY culturing conditions. NPY increases the proportion of mitotic nestin and beta-tubulin positive cells. 3 day-old cultures exposed to a $4 \mathrm{hr}$ pulse of BrdU and $1 \mathrm{mM}$ NPY have an increased proportion of $\beta$-tubulin/ BrdU $(\mathrm{G})$ and nestin / $\operatorname{BrdU}(\mathrm{H})$, cells relative to cells in control media indicative of a proliferative effect of NPY on these cell phenotypes. *, $\mathrm{p}<0.05$. BrdU = bromodeoxyuridine, 


\section{Subgranular Zone Cell Composition}

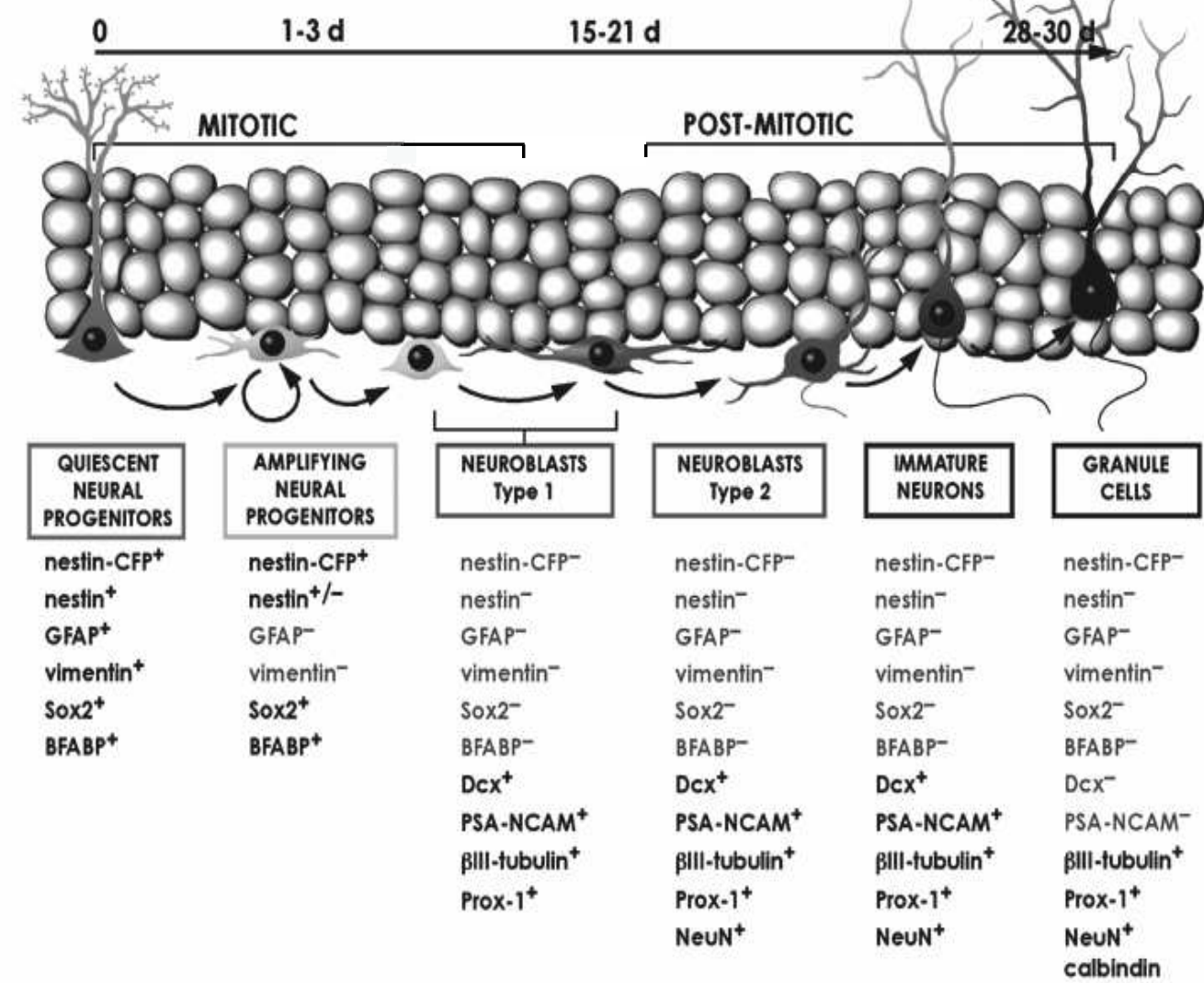

$\begin{array}{lllll}\text { Type } 1 & \text { Type 2a } & \text { Type 2b } & \text { Type 2c } & \text { Type } 3 \text { (Kempemann et a 2004) }\end{array}$
Type A
Type D1
Type D2 Type D3 (Serietal 2004)

Modified and reproduced with permission from; Encinas, J.M., A. Vaahtokari, and G. Enikolopov, Fluoxetine targets early progenitor cells in the adult brain. Proc Natl Acad Sci U S A, 2006. 103(21): p. 8233-8.

Copyright 2006 National Academy of Sciences, U.S.A. 
Figure 3

A

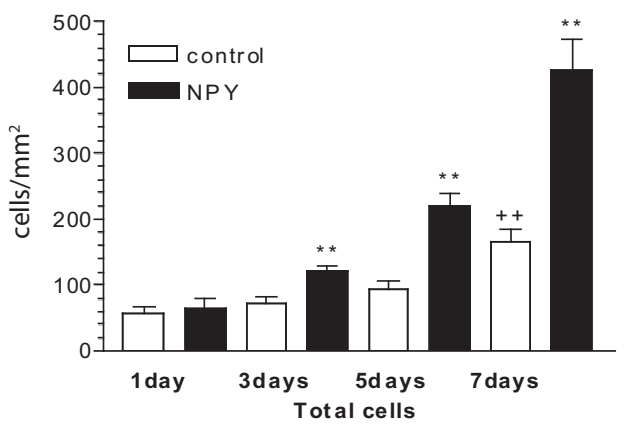

C

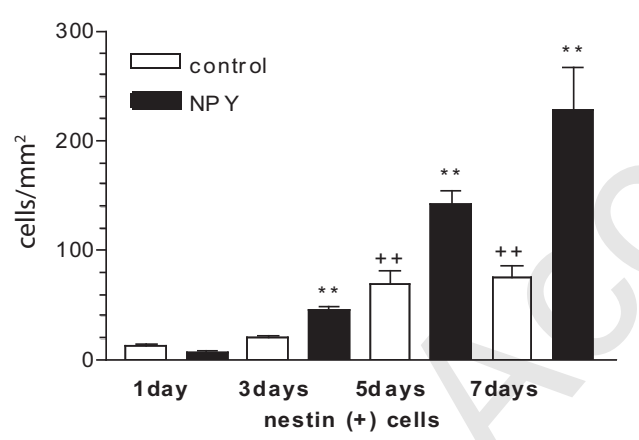

$\mathbf{F}$

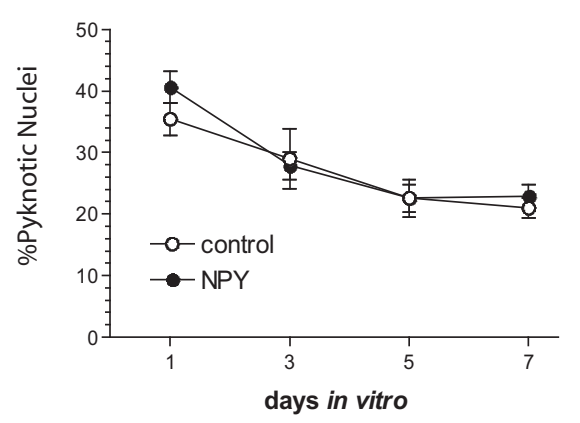

E

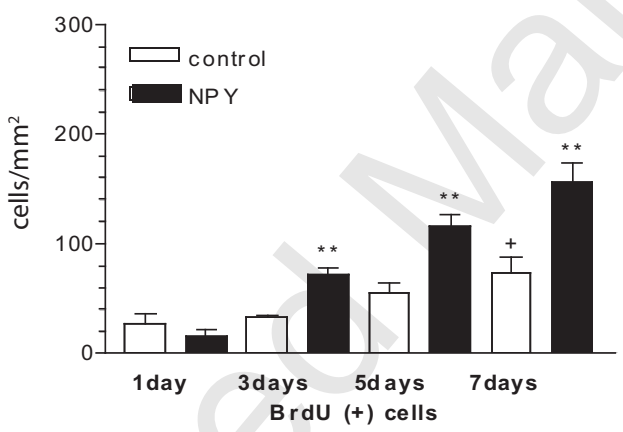

D

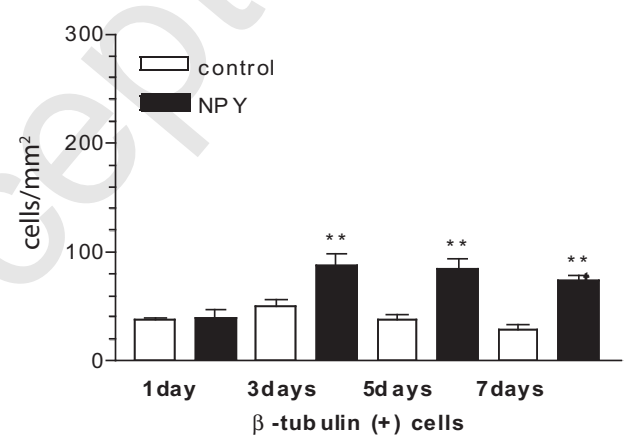

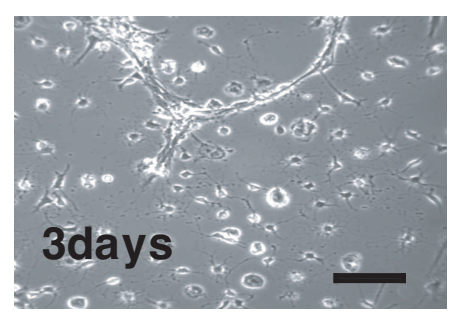
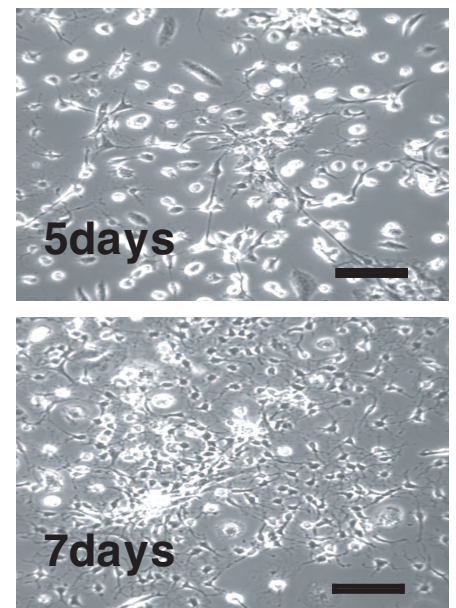

G

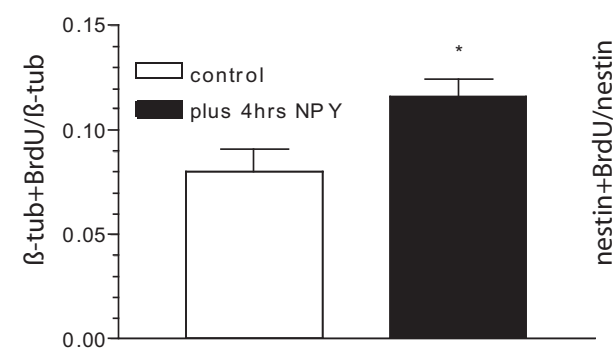

H

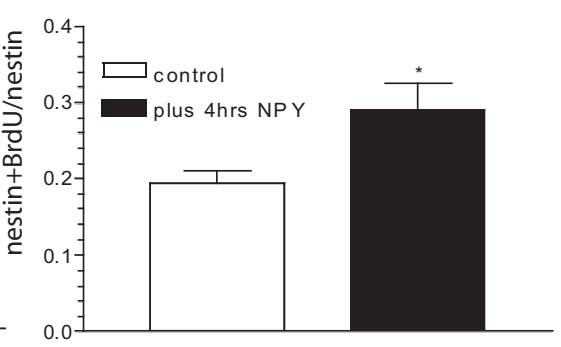

